\title{
Ustekinumab associated bullous pemphigoid in a psoriasis patient and a review of the literature
}

\author{
Psoriazis hastasında ustekinumab ile ilișkili gelișen büllöz pemfigoid ve literatür \\ derlemesi
}

\section{Seçil Vural, ๑ Mustafa Gündoğdu, ๑ Pelin Ertop, ๑ Hatice Șanlı, ๑ Pınar Korkmaz, ๑ Aylin Okçu Heper*, ๑ Nihal Kundakcı}

Ankara University Faculty of Medicine, Department of Dermatology; *Department of Pathology, Ankara, Turkey

\begin{abstract}
Ustekinumab is a Food and Drug Administration-approved (2009) novel treatment for psoriasis patients. This anti-interleukin-12/23p40 monoclonal antibody is effective in the treatment of plaque psoriasis and psoriatic arthritis. Several drugs, including anti-tumor necrosis factoralpha agents, used for psoriasis have been reported to induce or cause bullous pemphigoid (BP). A psoriasis patient presented with bullous lesions appearing on the extremities, groin, and axillary region four weeks after ustekinumab therapy. The patient was diagnosed with druginduced BP. Ustekinumab was discontinued and the patient was treated with topical steroids and acitretin. The BP lesions did not recur in the twelve-month follow-up, after cessation of the steroids. Even though several drugs are related to the induction of BP, ustekinumab is included in this list recently. The resolution of BP after discontinuation of ustekinumab favors the diagnosis of drug-induced BP.

Keywords: Psoriasis, ustekinumab, adverse effect, bullous pemphigoid
\end{abstract}

Öz

Ustekinumab, psoriazis hastaları için Gıda ve Illaç İdaresi tarafından 2009 ylında onaylanan yeni bir tedavi ajanıdır. Interlökin-12/23'ün p40 subünitini hedef alan bu monoklonal antikor, plak psoriazis ve psoriatik artrit tedavisinde etkilidir. Literatürde şimdiye kadar anti-tümör nekroz faktörü-alfa grubu ilaçların da içinde yer aldığı pek çok ilaç büllöz pemfigoid (BP) gelişiminden sorumlu tutulmuştur. Kliniğimize bir psoriazis hastası ilk ustekinumab enjeksiyonundan dört hafta sonra ekstremiteler, kasık ve aksillar bölgede büllöz lezyonlar ile başvurdu. Hastaya ilaçla indüklenen BP tanısı koyuldu. Ustekinumab kesildi ve hasta topikal steroid ve asitretin ile tedavi edildi. BP steroid kesilmesinden sonraki on iki aylık takipte tekrarlamadı. BP'ye sebep olan ilaçların olduğu listeye ustekinumab çok yakın bir zamanda eklenmiştir. Ustekinumab'ın kesilmesinden sonra BP'nin tekrarlamaması ilaç ilişkili BP tanısını desteklemektedir.

Anahtar Kelimeler: Psoriazis, ustekinumab, yan etki, büllöz pemfigoid

\section{Introduction}

Psoriasis is a common chronic inflammatory dermatologic disease. The pathogenesis of psoriasis is complicated and not fully understood yet. However, the underlying pathology involves T cells and T cell interactions with innate immunity ${ }^{1,2}$. Bullous pemphigoid (BP), on the other hand, is an acquired autoimmune dermatitis with autoantibodies against the basement membrane zone ${ }^{3}$. BP mainly affects the elderly.

Address for Correspondence/Yazışma Adresi: Seçil Vural MD, Ankara University Faculty of Medicine, Department of Dermatology, Ankara, Turkey Phone: +90 5054324682 E-mail: secilsaral@gmail.com

Received/Geliş Tarihi: 03.11.2017 Accepted/Kabul Tarihi: 09.10.2018 ORCID ID: orcid.org/0000-0001-6561-196X

CCopyright 2019 by Turkish Society of Dermatology and Venereology

Turkderm-Turkish Archives of Dermatology and Venereology published by Galenos Yayınevi. 
The pathogenesis of drug-induced BP is not fully understood but a strong correlation with medications exists. Over the years, more than 50 medications have been associated with $\mathrm{BP}^{4,5}$. Classically, druginduced BP arises in a patient with multiple drug regimens and a newly introduced drug. Medication-related BP mainly occurs in a younger group of patients when compared to classical BP. The lesions respond well to systemic steroids and relapses rarely occur after discontinuation of the inciting drug.

Ustekinumab is a novel treatment for psoriasis and psoriatic arthritis in the structure of anti-Interleukin-12 (IL-12)/23p40 monoclonal antibody. Several drugs and light therapy used for psoriasis have been reported to induce or cause BP.

\section{Case Report}

A 58-year-old patient with a 10-year history of psoriasis was admitted to our outpatient clinic with itching and bullous lesions on the trunk and extremities along with generalized psoriatic plaques. In the past, the patient had used methotrexate (cumulative dose $1500 \mathrm{mg}$ ), cyclosporine, and acitretin for psoriasis. His medical history included chronic renal failure, hypertension, and hepatosteatosis. He used amlodipine for his hypertension for years and occasionally used paracetamol for headache and arthralgia.

For psoriasis, the recent choice of treatment was adalimumab. However, after three months of adalimumab therapy, the treatment was switched to ustekinumab (Stelara ${ }^{\circledR}$; Janssen Biotech, Inc., Horsham, PA) because of resistant and generalized psoriatic lesions. A one-month interval existed between the last dose of adalimumab and ustekinumab injection.

One month after the initial injection of $45 \mathrm{mg}$ ustekinumab, bullous lesions formed on erythematous urticarial plaques and psoriatic lesions appeared. The lesions were prominent on the axillary fossa and inguinal region. Laboratory tests revealed mild anemia (Hg: 12.7, normal ranges: 13.1-17.2 g/dL), eosinophilia (4.8, normal ranges:

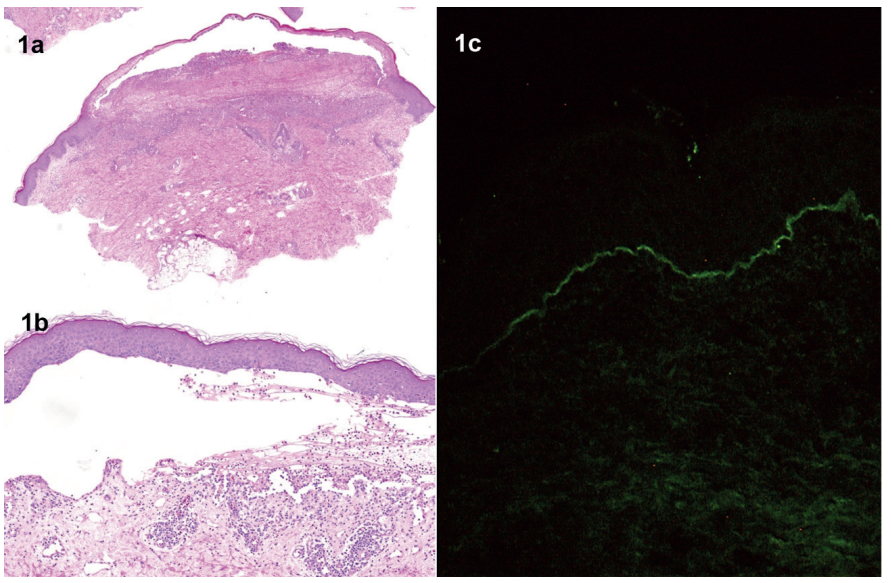

Figure 1. a) Subepidermal blister formation (hematoxylin and eosin, x40), b) an inflammatory infiltrate composed predominantly of eosinophils and neutrophils in the dermis and bullous cavity (hematoxylin and eosin, x100), c) bullous pemphigoid, direct immunofluorescence. There is linear deposition of immunoglobulin $\mathrm{G}$ in the basement membrane zone with direct immunofluorescence
0-3\%), and increased serum C-reactive protein (9.2, normal ranges: 0-3 $\mathrm{mg} / \mathrm{L}$ ) levels. Serum creatinine level was also elevated to $2.07 \mathrm{mg} / \mathrm{dL}$. Skin biopsies from the lesional and perilesional skin were examined (Figure 1). Light microscopic examination revealed bullae with subepidermal cleavage and dermal infiltrate of eosinophils. In addition, direct immunofluorescence study of the perilesional skin showed subepidermal linear immunoglobulin G (lgG), C3, and C4 staining. The diagnosis was BP with dermatopathological findings. Our patient received a Naranjo adverse drug reaction probability scale score of 8 and a modified Naranjo scale score of 5 , indicating a probable drug reaction ${ }^{6,7}$.

After the initial administration of ustekinumab, the treatment was discontinued. The bullous lesions were treated with topical mometasone furoate, clobetasol propionate, and oral acitretin (35 $\mathrm{mg} /$ day) was started for the psoriatic plaques. After two weeks of treatment, development of new lesions stopped and pruritus decreased. BP improved clinically. The topical steroid application was ceased after three weeks. Bullous lesions disappeared with slight hyperpigmentation and the patient continued treatment with acitretin for psoriasis. No relapses occurred in the twelve-month follow-up. Inflammatory subtype of acquired epidermolysis bullosa (AEB) can simulate BP both histopathologically and clinically in some cases and it was an important differential diagnosis in our case. To differentiate these two diseases, salt split test in pathological examination is necessary because in both conditions, linear lgG deposition is observed in the basement membrane. A limitation of our case was the lack of salt-split, ELISA or Western blotting to confirm the diagnosis of BP. We favored the diagnosis of BP because AEB is a chronic disease which requires long-term systemic immunosuppressive treatment to suppress symptoms. On the other hand, in our patient, the lesions disappeared without the need for immunosuppressive treatment after ustekinumab was halted and acitretin treatment did not worsen the scenario.

\section{Discussion}

Several mechanisms have been proposed for the etiopathogenesis of drug-related BP. In certain individuals, some drugs may cause an unwanted immune dysregulation leading to inactivation of the endogenous regulatory processes, resulting in a BP phenotype ${ }^{8,9}$. Other drugs may act as antigenic haptens that bind and modify proteins in the basement membrane. This may expose a previously hidden antigenic site and induce an autoimmune cascade ${ }^{10}$.

Ustekinumab, a fully human $\lg \mathrm{G} 1 \kappa$ monoclonal antibody, binds to the common p40 subunit of IL-12 and IL-23, blocking the activation of the receptors of these cytokines in dendritic cells and monocytes. Recently, ustekinumab has been reported to induce BP in a patient with psoriatic onycho-pachydermo-periostitis after 18 months of use. Similar to our case, the patient had previously used an anti-tumor necrosis factor (TNF) inhibitor (infliximab) before ustekinumab ${ }^{11}$.

The coexistence of psoriasis and BP has been reported in approximately 40 patients $^{3}$. It is still debated whether the co-occurrence of these two diseases is a coincidence or a pathogenic relationship. In both diseases, the basement membrane zone is involved in the pathogenesis. 
Table 1. Literature review of cases with biologic drug-induced bullous pemphigoid

\begin{tabular}{|c|c|c|c|c|c|c|c|c|}
\hline Case & Drug & Age & Disease & $\begin{array}{l}\text { Duration of } \\
\text { biologic drug }\end{array}$ & Location & Tx BP & Tx Psoriasis & Reference \\
\hline 1 & Adalimumab & 50 & Psoriasis & 3 months & Trunk, limbs & TS, SS & - & $\begin{array}{l}\text { Stausbol-Gron et } \\
\text { al. }^{13}\end{array}$ \\
\hline 2 & Adalimumab & 49 & U. Colitis & 1,5 years & $\begin{array}{l}\text { The superior forehead, } \\
\text { scalp, trunk, hands and } \\
\text { feet. }\end{array}$ & $\begin{array}{l}\text { TS, SS, Azt, } \\
\text { IVIG }\end{array}$ & - & Wessman et al..$^{14}$ \\
\hline 4 & Etanercept & 61 & $\begin{array}{l}\text { Rheumatoid } \\
\text { arthritis }\end{array}$ & 2 months & Trunk and extremities & SS & - & Mochizuki et al. ${ }^{16}$ \\
\hline 5 & Etanercept & 63 & Psoriasis & 2 months & $\begin{array}{l}\text { Arms and upper } \\
\text { back }\end{array}$ & TS & - & Kluk et al. ${ }^{17}$ \\
\hline 6 & Etanercept & 65 & $\begin{array}{l}\text { Rheumatoid } \\
\text { arthritis }\end{array}$ & $\begin{array}{l}2 \\
\text { years }\end{array}$ & $\begin{array}{l}\text { Trunk, upper } \\
\text { and lower limbs and oral } \\
\text { mucosa }\end{array}$ & $S S+M t x$ & - & Bordignon et al. ${ }^{18}$ \\
\hline 9 & Secukinumab & 65 & Psoriasis & 1 week & Upper limbs and trunk & TS & Secukinumab & $\mathrm{Ho} \mathrm{PH}$ and $\mathrm{Tsai}^{20}$ \\
\hline 10 & Ustekinumab & 63 & Psoriasis & 18 months & Trunk, extremity & SS & - & Nakayama et al. ${ }^{11}$ \\
\hline 11 & Ustekinumab & 62 & Psoriasis & 40 weeks & $\begin{array}{l}\text { Upper thighs, lower neck, } \\
\text { and upper trunk }\end{array}$ & TS & - & Le Guern et al. ${ }^{21}$ \\
\hline 12 & Ustekinumab & 58 & Psoriasis & 1 month & $\begin{array}{l}\text { Intertriginous areas, } \\
\text { generalized }\end{array}$ & TS & Acitretin & Our case \\
\hline
\end{tabular}

Disruption of the basement membrane and keratinocytes with treatment and/or previous dermatosis may change the antigenicity of the basement membrane and facilitate autoantibody production ${ }^{3}$. This is supported by reports of blisters initially appearing on psoriatic lesions ${ }^{12}$. The patient in this case had blisters on both psoriatic plaques and a psoriasis-naive erythematous base. This may be explained by BP antigen spreading to psoriasis-free areas after the initial pathological process. The reported cases of patients with biologic drug-induced BP are summarized in Table $1^{5,11,13-21}$. Most of the patients received these drugs for psoriasis (9/12), only 2 patients were reported to have rheumatoid arthritis and 1 ulcerative colitis. In most of the cases, the biologic drug was stopped after development of BP lesions and psoriasis was treated with an alternative drug. In only one case, secukinumab was reported to be the culprit drug, however, treatment with secukinumab was started again after a while but rechallenge did not result in reemergence of $\mathrm{BP}$ lesions.

The immune system is a very sensitive system prone to imbalance. It is already known that TNF-targeted treatments used in psoriasis and rheumatoid arthritis are related to autoimmune diseases with an increased incidence of anti-double-stranded-DNA production and exacerbation of multiple sclerosis ${ }^{22}$. Biologics modify the immune system through cytokines and TNF- $\alpha$ inhibition. The immune system may mediate different pathways in susceptible individuals when one path is blocked by a drug action, leading to unexpected autoimmune processes. It is not possible to definitely say that ustekinumab is the direct cause of BP in this patient. However, rapid onset of BP after the initiation of ustekinumab therapy and amelioration of lesions after cessation of the treatment and lack of recurrence favors druginduced BP.

Acknowledgements: We would like to thank Prof. Dr. JC Prinz for critical reviewing of the paper.

\section{Ethics}

Informed Consent: We received informed consent form from patient. Peer-review: Externally peer-reviewed.

\section{Authorship Contributions}

Surgical and Medical Practices: S.V., A.O.H., Concept: S.V., M.G., Design: S.V., H.Ş., Data Collection or Processing: M.G., P.K., Analysis or Interpretation: S.V., N.K., Literature Search: S.V., P.E., Writing: S.V., M.G. Conflict of Interest: No conflict of interest was declared by the authors.

Financial Disclosure: The authors declared that this study received no financial support.

\section{References}

1. Bolognia JL, Jorizzo JL, Rapini RP. Dermatology. Vol 1. 2 ed2008

2. Prinz JC. Autoimmune aspects of psoriasis: Heritability and autoantigens. Autoimmun Rev 2017;16:970-9. 
3. Wilczek A, Sticherling M. Concomitant psoriasis and bullous pemphigoid: coincidence or pathogenic relationship? Int J Dermatol 2006;45:1353-7.

4. Vassileva S. Drug-induced pemphigoid: bullous and cicatricial. Clin Dermatol 1998;16:379-87.

5. Duong TA, Buffard V, Andre $C$, et al. Efalizumab-induced bullous pemphigoid. J Am Acad Dermatol 2010;62:161-2.

6. Naranjo CA, Busto $U$, Sellers EM, et al. A method for estimating the probability of adverse drug reactions. Clin Pharmacol Ther 1981;30:239-45.

7. Murayama H, Sakuma M, Takahashi $Y$, et al. Improving the assessment of adverse drug reactions using the Naranjo Algorithm in daily practice: The Japan Adverse Drug Events Study. Pharmacol Res Perspect 2018;6.

8. Newport MJ, Goetghebuer T, Marchant A. Hunting for immune response regulatory genes: vaccination studies in infant twins. Expert Rev Vaccines 2005:4:739-46

9. Stavropoulos PG, Soura E, Antoniou C. Drug-induced pemphigoid: a review of the literature. J Eur Acad Dermatol Venereol 2014;28:1133-40.

10. Lee JJ, Downham TF 2nd. Furosemide-induced bullous pemphigoid: case report and review of literature. J Drugs Dermatol 2006;5:562-4.

11. Nakayama C, Fujita $Y$, Watanabe $M$, et al. Development of bullous pemphigoid during treatment of psoriatic onycho-pachydermo periostitis with ustekinumab. J Dermatol 2015;42:996-8.

12. Kobayashi TT, Elston DM, Libow LF, et al. A case of bullous pemphigoid limited to psoriatic plaques. Cutis 2002;70:283-7.

13. Stausbol-Gron B, Deleuran M, Sommer Hansen E, et al. Development of bullous pemphigoid during treatment of psoriasis with adalimumab. Clin Exp Dermatol 2009;34:285-6.
14. Wessman LL, Blixt EK, Wetter DA, et al. Adalimumab-associated bullous pemphigoid in a patient with ulcerative colitis. JAAD Case Rep 2017;3:33941

15. Wilmer EN, Becker N, Chen A, et al. Etanercept-induced generalization of chronic, localized, anogenital bullous pemphigoid in a psoriatic patient. JAAD Case Rep 2016;2:25-7.

16. Mochizuki M, Fujine E, Tawada C, et al. Pemphigoid nodularis possibly induced by etanercept. J Dermatol 2013;40:578-9.

17. Kluk J, Goulding JM, Bhat J, et al. Drug-induced bullous pemphigoid: cases triggered by intravenous iodine and etanercept. Clin Exp Dermatol 2011;36:871-3.

18. Bordignon M, Belloni-Fortina A, Pigozzi B, et al. Bullous pemphigoid during long-term TNF-alpha blocker therapy. Dermatology 2009;219:357-8.

19. Monnier-Murina K, Du Thanh A, Merlet-Albran S, et al. Bullous pemphigoid occurring during efalizumab treatment for psoriasis: a paradoxical autoimmune reaction? Dermatology 2009;219:89-90.

20. Ho PH, Tsai TF. Development of bullous pemphigoid during secukinumab treatment for psoriasis. J Dermatol 2017;44:220-1.

21. Le Guern A, Alkeraye $S$, Vermersch-Langlin A, et al. Bullous pemphigoid during ustekinumab therapy. JAAD Case Rep 2015;1:359-60.

22. Ramos-Casals M, Brito-Zeron P, Munoz $S$, et al. Autoimmune diseases induced by TNF-targeted therapies: analysis of 233 cases. Medicine (Baltimore) 2007;86:242-51 